\title{
PENGUJIAN MIKROORGANISME LOKAL ( MOL) LIMBAH SAYURAN TERHADAP PERTUMBUHAN DAN PRODUKSI TANAMAN SAWI ( Brassica juncea L)
}

\author{
Sri Utami Lestari, Neng Susi, Enny Mutryarny \\ Fakultas Pertanian Universitas Lancang Kuning \\ Jl.Yos Sudarso Km.8 Rumbai Pekanbaru
}

\begin{abstract}
Nowadays people are increasingly concerned about the importance of product quality. The use of fertilizers derived from organic materials is believed to bring more benefits to agricultural products where products become healthier, environmentally friendly and can reduce the negative impact of chemicals that are harmful to humans and the environment. Veg mole is expected in addition to its local microorganisms also Nitrogen element content can increase the growth and production of mustard plants.

The purpose of this study is to determine the effect and to get a good dose of MOL vegetable waste on the growth and production of mustard plants.The experiment was conducted experimentally using non factorial completely Randomized Design (RAL) consisting of 5 treatment levels and 4 replications to obtain 20 experimental units. Each plot consists of 16 plants and 4 plants as sample. The level of treatment is as follows: Mo: Without giving MOL of vegetable waste, M1: Giving MOL vegetable waste $75 \mathrm{cc} / 1$ water, M2: Giving of MOL vegetable waste $150 \mathrm{cc} / 1$ water, M3: Giving MOL vegetable waste $225 \mathrm{cc} / 1$ water, M4: Giving MOL vegetable waste $300 \mathrm{cc} / 1$ water

The result of this research can be concluded that vegetable MOL has no significant effect on all observed parameters, ie plant height $(\mathrm{cm})$, number of leaf (strands), leaf length $(\mathrm{cm})$, leaf width $(\mathrm{cm})$, wet weight $(\mathrm{g})$ consumption $(\mathrm{g})$.
\end{abstract}

Keywords: vegetable waste, mustard greens

\section{BAB 1 . PENDAHULUAN}

Sawi (Brassica juncea L) merupakan jenis sayuran yang mempunyai manfaat sebagai nutrisi bagi masyarakat, tanaman ini dapat tumbuh di dataran rendah maupun di dataran tinggi. Sawidapat tumbuh dengan baik apabila tumbuh pada media yang tepat yaitu pada tanah yang gembur banyak mengandung humus dan bahan organik. Pertumbuhan tanaman sawi yang optimum di tanam pada tanah yang mempunyai $\mathrm{pH}$ berkisar antara 67.

Tanah merupakan media tumbuh tanaman dan tempat sumber makanan bagi tanaman. Untuk mendapatkan hasil yang maksimum, tanaman harus tumbuh secara maksimum, diantaranya harus didukung oleh kondisi tanah yang mampu menyediakan semua kebutuhan tanaman akan unsur-unsur hara dalam jumlah yang cukup dan berimbang atau dengan kata lain tanah harus subur.

Tanamansawi akan tumbuh dengan baik pada media tanam yang sanggup menyediakan unsur hara yang cukup, disamping faktor-faktor lain seperti; varietas yang digunakan, kondisi lingkungan, serta faktor iklim yang cocok bagi tanaman. Namun pada umumnya permasalahan yang ditemui di lapangan adalah tidak semua media tanam dapat menyediakan unsur hara yang dibutuhkan, terutama pada tanah Podzdolik 
Merah Kuning (PMK) yang bersifat miskin unsur hara makro (Nitrogen, Fospor dan Kalium), sehingga perlu memberikan unsur hara tambahan yang cukup melalui pemupukan.

Saat ini masyarakat semakin peduli akan pentingnya kualitas produk. Penggunaan pupuk - pupuk yang berasal dari bahan organik dipercaya membawa manfaat lebih bagi produk - produk pertanian dimana produk menjadi lebih sehat, ramah lingkungan dan dapat mengurangi dampak negatif dari bahan kimia yang berbahaya bagi manusia dan lingkungan.

Menurut Indriani (2004) pupuk an organik dapat menimbulkan ketergantungan dan dapat membawa dampak kurang baik misalnya tanah menjadi rusak akibat penggunaan yang berlebihan dan terusmenerus akan menyebabkan tanah menjadi keras, air tercemar dan keseimbangan alam akan terganggu.

Oleh karena itu diperlukan asupan unsur hara yang bisa mengefisienkan pemakaian pupuk anorganik dan aman bagi lingkungan.Limbah merupakan bahan yang tidak mempunyai nilai atau tidak berharga lagi. Limbah merupakan permasalahan yang masih sulit untuk dipecahkan namun sepertinya belum terlihat adanya langkah yang kongkrit guna menanggulangi masalah limbah, terutama limbah sayuran, konsekuensi dari adanya aktivitas manusia seiring meningkatnya populasi penduduk dan pertumbuhan ekonomi saat ini pengolahan limbah sayuran sebagian besar daerah terutama di Kelurahan Maharatu Kecamatan Marpoyan Damai Kota Pekanbarumasih menimbulkan permasalahan yang sulit dikendalikan. Timbunan limbah sayuranyang tidakterkendalikan yang kemudian berdampak negatif yang akan mempengaruhi berbagai segi kehidupan, baik secara langsung maupun tidak langsung. Pada permasalahan di lingkungan yang menjadi sumber bakteri penyakit, pencemaran udara, tanah, air, dan lebih jauh lagi terjadinya bencana ledakan gas metan, serta pencemaran udara akibat pembakaran terbuka yang menyebabkan pemanasan global.

Peningkatan produksi limbah sangat mempengaruhi pemanasan global yang memicu terjadinya perubahan iklim. Dengan pengolahan yang tepat sesuai dengan lingkungan dan keberadaan pada lingkungan diharapkan mampu menjadikan lingkungan bersih,sehat dan nyaman,selain itu limbah yang tepat guna dapat menghasilkan nilai guna yang akan menambahkan penghasilan.

Harga pupuk yang semakin tinggi karena pencabutan subsidi dari Pemerintah dan semakin sedikitnya bahan baku pupuk yang harus diimporkan, maka pemanfaatan limbah atau sampah organik menjadi alternatif pengguanaan pupuk yang tepat selain juga dapat mengurangi dampak negatif penggunaan pupuk an organik, karena pupuk yang diolah dari limbah atau sampah organik lebih ramah lingkungan.

Sawi merupakan salah satu komoditi horikultura yang memiliki prospek dan nilai komersial yang cukup baik. Meningkatnya kesadaran penduduk akan kebutuhan gizi menyebabkan bertambahnya permintaan akan sayuran. Kandungan gizi pada sayuran terutama vitamin dan mineral tidak dapat disubstitusi melalui makanan pokok (Nazaruddin, 2003).

Bagian tanaman sawi yang dikonsumsi adalah bagian daun sehingga pupuk yang diberikan sebaiknya mengandung nitrogen $(\mathrm{N})$ tinggi.Sifat pupuk $\mathrm{N}$ mudah menguap dan ketika musim penghujan dapat terjadi pencucian.Ketika tanaman kekurangan unsur hara nitrogen menunjukkan gejala daun menguning, sehingga pengaplikasian pupuk $\mathrm{N}$ kepada tanaman harus tetap terpenuhi.

\subsection{Rumusan Masalah}

Berdasarkan permasalahan tersebut alternative yang dapat dilakukan yaitu denganmemanfaatkan limbah sayuranyang sudah tidak bisa dimakan lagi, dimanfaatkan untuk pembuatan MOL (Mikroorganisme Lokal). Mikroorganisme Lokal Sayuran adalah larutan hasil fermentasi yang berbahan dasar 
sawi.Dalam Mol sayuran ini diharapkan selain kandungan mikroorganisme local nya juga kandungan unsur Nitrogen dapat meningkatkan pertumbuhan dan produksi tanaman sawi. Berdasarkan permasalahan tersebut penulis tertarik melakukan penelitian untuk menguji MOL limbah sayuran yang tersedia di daerah setempat dengan judul"Pengujian Mikroorganisme Lokal (MOL) Limbah Sayuran Terhadap Pertumbuhan Dan Produksi Tanaman Sawi ".

\section{BAB 2. TUJUAN DAN MANFAAT PENELITIAN}

\subsection{Tujuan Penelitian}

Adapun tujuan dilakukannya penelitian ini adalah untuk mengetahui pengaruh dan untuk mendapatkan dosis MOL limbah sayuran yang baik terhadap pertumbuhan dan produksi tanaman sawi

\subsection{Manfaat Penelitian}

Manfaat dari penelitian ini adalah

1. Pemanfaatan limbah sayuran menjadi pupuk organik cair yang bermanfaat bagi tanaman sehingga mengurangi dampak lingkungan akibat limbah sayuran

2. Peningkatan produksi yang berdampak pada peningkatan pendapatan petani

3. Sebagai salah satu upaya menciptakan kemandirian petani dalam usaha pertanian berkelanjutan

\section{BAB 3. METODE PENELITIAN}

\subsection{Tempat dan waktu}

Penelitianini dilaksanakan di Kebun Percobaan Fakultas Pertanian Universitas Lancang Kuning KM 08 Rumbai Kota Pekanbarudengantopografidatar,

danketinggian tempat 16 meter daripermukaanlaut,denganjenistanahPodzolik Merah Kuning (PMK). Penelitian dilaksanakan selama 3 bulan dari bulan Maret sampai dengan Mei 2017.

\subsection{Bahan dan Alat}

Bahan yang digunakan antara lain: benih Sawi varietas Kumala, pupuk kandang sapi, polybag dan MOL Sayuran. Sedangkan alat yang digunakan cangkul, gembor, ember, penggaris, gelas ukur.

\subsection{Metode Penelitian}

Penelitian dilaksanakan secara eksperimen dengan menggunakan Rancangan Acak Lengkap (RAL) non factorial yang terdiri dari 5 taraf perlakuan dan 4 kali ulangan sehingga diperoleh 20 unit percobaan. Setiap plot terdiri dari 16 tanaman dan 4 tanaman sebagai sample.

Adapun taraf perlakuannya adalah sebagai berikut :

Mo : Tanpa pemberian MOL limbah sayuran

M1 : Pemberian MOL limbah sayuran75 cc/l air

M2 : Pemberian MOL limbah sayuran $150 \mathrm{cc} / \mathrm{l}$ air

M3 : Pemberian MOL limbah sayuran $225 \mathrm{cc} / 1$ air

M4 :Pemberian MOL limbah sayuran $300 \mathrm{cc} / \mathrm{l}$ air

Adapun model matematik RAL adalah sebagai berikut :

$\mathrm{Y}_{\mathrm{ij}=} \mu+\mathrm{H}_{\mathrm{i}}+\epsilon_{\mathrm{ij}}$ Dimana :

$\mathrm{Y}_{\mathrm{ij}}=$ Hasil pengamatan pada perlakuan ke-I dan ulangan ke-j

$\mu=$ Nilai tengah

$\mathrm{H}_{\mathrm{i}}=$ Pengaruh perlakuan MOL (M) pada taraf ke-i

$€_{\mathrm{ij}}=$ Pengaruh galat akibat $] \quad$ z-I dan ulangan ke-j

(Surtinah, 2008)

Data yang diperoleh dianalisis dengan menggunakan sidik ragam, $F$ hitung lebih kecil $\mathrm{F}$ table, maka tidak dilakukan uji lanjut.

\subsection{PelaksanaanPenelitian}

\subsubsection{Pengolahan Tanah}

Pengolahan tanah dilakukan dua kali, .Pengolahan tanah pertama bertujuan untuk membalikkan tanah dengan kedalaman 0-20 $\mathrm{cm}$ dan di diamkan selama seminggu. Pengolahan tanah kedua dilakukan setelah pengolahan tanah pertama bertujuan untuk menggemburkan tanah, bersamaan dengan itu 
dilakukan pembuatan plot dengan ukuran $0,5 \mathrm{x}$ 0,5 m. Pemberian pupuk kandang dilakukan bersamaan dengan pengolahan tanah kedua sebanyak 10 ton/Ha $(0,5 \mathrm{~kg} / \mathrm{plot})$ dengan cara mencampur dan mengaduk rata dalam plot. Setelah diberi pupuk kandang maka dilakukan perlakuan pertama dengan memberikan MOL sayuran sesuai dengan dosis perlakuan.

\subsubsection{Pemasangan Label}

Pemasangan label dilapangan dilakukan sesudah pembuatan plot, label terbuat dari map tulang dengan ukuran $20 \times 20$ $\mathrm{cm}$ dengan warna dasar kuning dan tulisan hitam. Label diberikan pada tiap-tiap plot sesuai dengan layout percobaan.

\subsubsection{Perlakuan}

MOL limbah sayuran diberikan pertama kali 1 minggu sebelum tanam bersamaan dengan pemberian pupuk kandang dengan cara disiramkan ke tanah. Pemberian selanjutnya dengan interval 1 minggu sekali. Untuk perlakuan yang tidak diberi MOL pada saat pemberian perlakuan penyiraman diberikan dengan air saja dengan volume yang sama dengan volume tanaman yang diberi perlakuan MOL .

\subsubsection{Persemaian}

Benih yang digunakan dalam penelitian terlebih dahulu direndam dengan air selama 30 menit kemudian dianginkan. Persemaian benih dilakukan dalam polybag kecil dan media yang digunakan untuk persemaian diambil dari tanah lapisan atas (topsoil) disekitar lokasi penelitian dan diberi pupuk kandang dengan perbandingannya $1: 2$, kemudian benih disemai lalu ditutup tanah setebal $1 \mathrm{~cm}$, penyiraman dilakukan setiap sore hari. Persemaian benih sawi dalam polybag selama 2 minggu dengan kriteria telah berdaun 4 helai, serta tinggi bibit sawi seragam dan bebas dari hama dan penyakit.

\subsubsection{Penanaman}

Setelah bibit berumur 2 minggu dipersemaian, bibit dipilih dengan pertumbuhan bibit yang baik, kriteria tinggi dan jumlah daun seragam yaitu 4 helai serta bebas dari hama dan penyakit. Pemindahan bibit beserta tanah dalam polybag dilakukan dengan cara menyobek polybag menggunakan pisau dan bibit ditanam ke plot penelitian dengan membuat lubang sedalam $10 \mathrm{~cm}$ dan jarak tanam $25 \times 25 \mathrm{~cm}$ (4 tanaman/plot), bibit ditanam sebatas leher akar kemudian tanah disekitar pangkal bibit dipadatkan.

\subsubsection{Penyulaman}

Penyulaman dilakukan setelah tanaman sawi berumur 1 minggu, ditanam dengan tanaman yang sama dipersemaian agar terjadi keseragaman dalam pertumbuhannya. Sedangkan kriteria tanaman yang digunakan sama dengan kriteria bibit sebelumnya.

\subsubsection{Pemeliharaan}

\subsubsection{Penyiraman}

Penyiraman dilakukan 2 kali sehari yaitu pagi dan sore hari.Saat hujan maka penyiraman tetap dilakukan dengan tujuan untuk membersihkan tanah-tanah yang menempel saat hujan. Penyiraman dilakukan dengan volume yang sama menggunakan gembor.

\subsubsection{Penyiangan}

Penyiangan dilakukan setiap ada gulma yang tumbuh, baik di dalam polybag maupun disekitar plot. Penyiangan didalam polybag dilakukan secara manual yaitu mencabut gulma yang tumbuh disekitar tanaman dengan hati - hati agar tanaman yang diteliti tidak terganggu, sedangkan penyiangan diluar polybag dilakukan dengan menggunakan cangkul.

\subsubsection{Panen}

Pemanenan tanaman sawi dilakukan setelah berumur 35 HST dan daun bagian bawah tanaman sawi berwarna kekuningan dan sudah hampir menyentuh tanah.

\subsection{Pengamatan}

\subsubsection{Tinggi Tanaman $(\mathrm{cm})$}

Pengukuran tinggi tanaman dilakukan dari pangkal batang sampai ujung daun dan tegak lurus dengan menggunakan mistar.

\subsubsection{Jumlah Daun Pertanaman (cm)}


Daun yang dihitung adalah semua daun pada tanaman termasuk daun muda yang baru dan telah membuka sempurna.

\subsubsection{Panjang Daun (cm)}

Pengamatan yang dilakukan adalah dengan mengukur daun terpanjang, panjang daun diukur dari dasar daun hingga ujung daun melalui ibu tulang daun dengan menggunakan mistar.

\subsubsection{Lebar Daun (cm)}

Pengukuran lebar daun diukur bagian daun yang terlebar dari daun yang terpanjang dan tegak lurus dengan ibu tulang daun, pengukuran dilakukan dengan menggunakan mistar.

\subsubsection{Berat Segar Tanaman (g)}

Seluruh bagian tanaman termasuk akarnya dicabut, lalu dibersihkan dengan air, kemudian dikering anginkan dan ditimbang.

\subsubsection{Berat Konsumsi (g)}

Pengamatan berat konsumsisetelah penimbangan berat segar, menimbang berat konsumsi tanaman dilakukan dengan pemotongan akar pada pangkal batang tanaman sawi kemudian ditimbang.

\section{BAB 4. HASIL DAN PEMBAHASAN}

\section{1. Hasil}

Hasil sidik ragam menunjukkan bahwa pemberian MOL sayuran berpengaruh tidak nyata terhadap semua parameter yang diamati, yaitu tinggi tanaman $(\mathrm{cm})$, jumlah daun (helai), panjang daun $(\mathrm{cm})$, lebar daun $(\mathrm{cm})$, berat brangkas basah(g) dan berat konsumsi (g). Berikut Rerata masing-masing parameter yang diamati :

\subsubsection{Tinggi Tanaman (cm)}

Rerata tinggi tanaman sawi (cm)akibat perlakuan MOL sayuran disajikan pada Tabel 1.

Tabel 1. Rerata Tinggi Tanaman Sawi (cm) Akibat Perlakuan MOL Sayuran

\begin{tabular}{|l|c|}
\hline \multicolumn{1}{|c|}{ Perlakuan MOL Sayuran } & Rerata Tinggi Tanaman (cm) \\
\hline M0 = Tanpa pemberian MOL & 21,45 \\
M1 = Pemberian MOL75 ml/1 & 22,48 \\
M2 = Pemberian MOL $150 \mathrm{ml} / 1$ & 15,20 \\
M3 = Pemberian MOL $225 \mathrm{ml} / 1$ & 18,27 \\
M4 = Pemberian MOL $300 \mathrm{ml} / 1$ & 16,47 \\
\hline
\end{tabular}

Tidak diuji lanjut

Tabel 1 dan grafik 1 diatas menunjukkan bahwa tinggi tanaman sawi setiap perlakukan mengalami fluktuasi hasil. Perlakuan M1 secara angka menunjukkan hasil tertinggi dibandingkan perlakuan yang lain meskipun hasil analisa sidik ragam menunjukkan bahwa pemberian MOL sayuran berpengaruh tidak nyata terhadap tinggi tanaman sawi. 
Gambar 1. Grafik Rerata Tinggi Tanaman Sawi (cm) Akibat Perlakuan MOL Sayuran

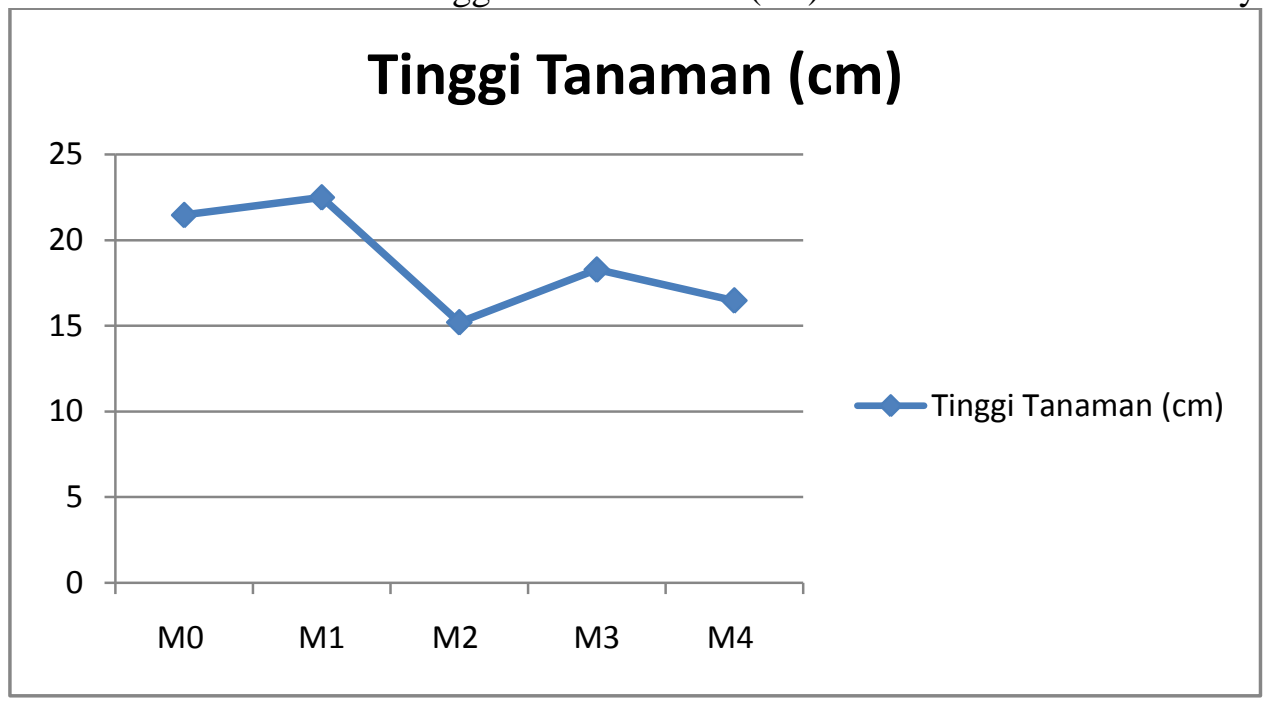

\subsubsection{Jumlah Daun Pertanaman (helai)}

Rerata jumlah daun tanaman sawiakibat perlakuan MOL sayuran disajikan pada Tabel 2.

Tabel 2. Rerata Jumlah Daun Tanaman Sawi (helai)Akibat Perlakuan MOL Sayuran

\begin{tabular}{|l|c|}
\hline \multicolumn{1}{|c|}{ Perlakuan MOL Sayuran } & $\begin{array}{c}\text { Rerata Jumlah Daun Tanaman } \\
\text { (helai) }\end{array}$ \\
\hline M0 = Tanpa pemberian MOL & 11,00 \\
M1 = Pemberian MOL75 ml/1 & 12,35 \\
M2 = Pemberian MOL $150 \mathrm{ml} / 1$ & 09,31 \\
M3 = Pemberian MOL $225 \mathrm{ml} / 1$ & 11,62 \\
M4 = Pemberian MOL $300 \mathrm{ml} / 1$ & 11,00 \\
\hline
\end{tabular}

Tidak diuji lanjut

Gambar 2. Grafik Rerata Jumlah Daun (helai) Tanaman Sawi Akibat Perlakuan MOL Sayuran

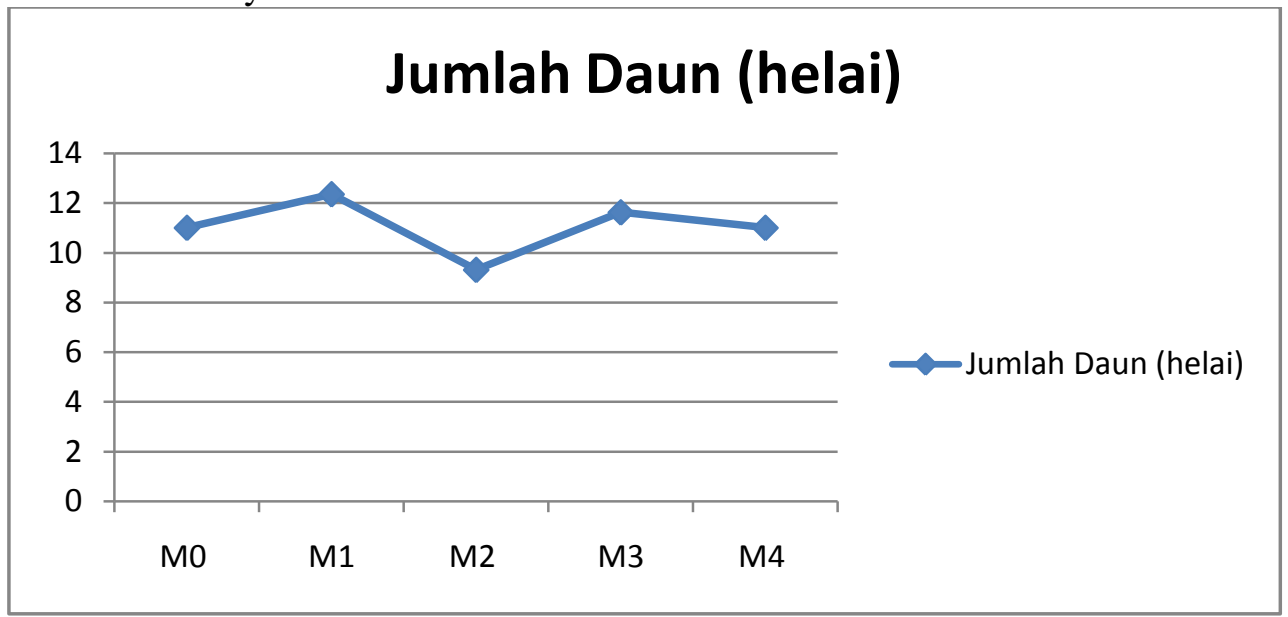

Tabel 2 dan grafik 2 diatas menunjukkan bahwa jumlah daun tanaman sawi setiap perlakukan mengalami fluktuasi hasil. Perlakuan M1 secara angka menunjukkan hasil tertinggi dibandingkan perlakuan yang 
lain meskipun hasil analisa sidik ragam menunjukkan bahwa pemberian MOL sayuran berpengaruh tidak nyata terhadap jumlah daun tanaman sawi.

\subsubsection{Panjang Daun (cm)}

Rerata panjang daun $(\mathrm{cm})$ akibat perlakuan MOL sayuran disajikan pada Tabel 3.

Tabel 3. Rerata Panjang Daun Tanaman Sawi (cm) Akibat Perlakuan MOL Sayuran

\begin{tabular}{|l|c|}
\hline \multicolumn{1}{|c|}{ Perlakuan MOL Sayuran } & Rerata Panjang Daun (cm) \\
\hline M0 = Tanpa pemberian MOL & 12,62 \\
M1 = Pemberian MOL75 ml/1 & 14,98 \\
M2 = Pemberian MOL $150 \mathrm{ml} / 1$ & 09,39 \\
M3 = Pemberian MOL 225 ml/1 & 11,13 \\
M4 = Pemberian MOL 300 ml/1 & 09,39 \\
\hline
\end{tabular}

Tidak diuji lanjut

Gambar 3. Grafik Rerata Panjang Daun Tanaman Sawi (cm) Akibat Perlakuan MOL Sayuran

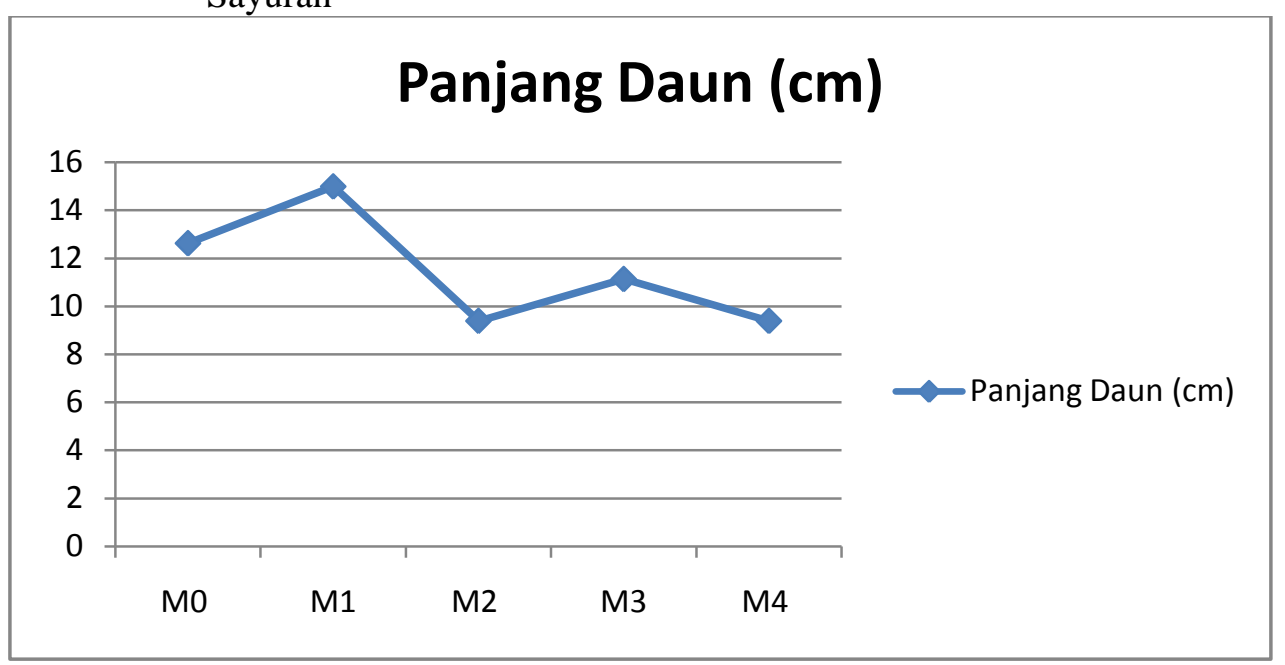

Tabel 3 dan grafik 3 diatas menunjukkan bahwa tinggi tanaman sawi setiap perlakukan mengalami fluktuasi hasil. Perlakuan M1 secara angka menunjukkan hasil tertinggi dibandingkan perlakuan yang lain meskipun hasil analisa sidik ragam menunjukkan bahwa pemberian MOL sayuran berpengaruh tidak nyata terhadap panjang daun tanaman sawi.

\subsubsection{Lebar Daun(cm)}

Rerata lebar daun (cm)akibat perlakuan MOL sayuran disajikan pada Tabel

Tabel 4. Rerata Lebar Daun Tanaman Sawi $(\mathrm{cm})$ Akibat Perlakuan MOL Sayuran

\begin{tabular}{|l|c|}
\hline \multicolumn{1}{|c|}{ Perlakuan MOL Sayuran } & Rerata Lebar Daun $(\mathbf{c m})$ \\
\hline M0 = Tanpa pemberian MOL & 07,00 \\
M1 = Pemberian MOL $75 \mathrm{ml} / 1$ & 07,34 \\
M2 = Pemberian MOL $150 \mathrm{ml} / 1$ & 05,19 \\
M3 = Pemberian MOL $225 \mathrm{ml} / 1$ & 06,14 \\
M4 = Pemberian MOL $300 \mathrm{ml} / 1$ & 05,63 \\
\hline
\end{tabular}

Tidak diuji lanjut

Gambar 4. Grafik Rerata Lebar Daun Tanaman Sawi (cm) Akibat Perlakuan MOL Sayuran 


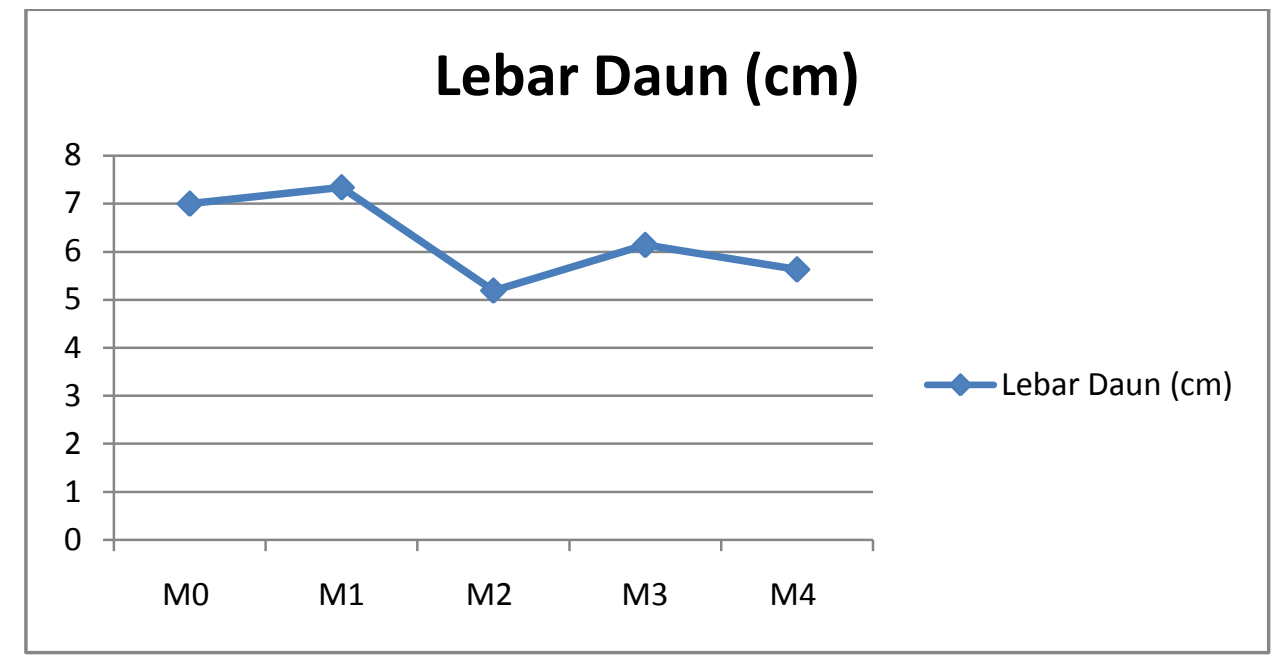

Tabel 4 dan grafik 4 diatas menunjukkan bahwa pemberian MOL menunjukkan bahwa lebar daun tanaman sayuran berpengaruh tidak nyata sawi setiap perlakukan mengalami terhadap lebar daun tanaman sawi.

fluktuasi hasil. Perlakuan M1 secara angka menunjukkan hasil tertinggi dibandingkan perlakuan yang lain meskipun hasil analisa sidik ragam

\subsubsection{Berat Segar Tanaman (g)}

Rerata berat segar tanaman (g)akibat perlakuan MOL sayuran disajikan pada Tabel 5.

Tabel 5. Rerata Berat Segar Tanaman Sawi(g) Akibat Perlakuan MOL Sayuran

\begin{tabular}{|l|c|}
\hline \multicolumn{1}{|c|}{ Perlakuan MOL } & $\begin{array}{c}\text { Rerata Berat Segar Tanaman } \\
(\mathbf{g})\end{array}$ \\
\hline M0 = Tanpa pemberian MOL & 19,53 \\
M1 = Pemberian MOL75 ml/1 & 22,71 \\
M2 = Pemberian MOL 150 ml/1 & 07,13 \\
M3 = Pemberian MOL 225 ml/1 & 10.00 \\
M4 = Pemberian MOL 300 ml/1 & 09,84 \\
\hline
\end{tabular}

Tidak diuji lanjut

Gambar 5.Grafik Rerata Berat Segar Tanaman Sawi (g) Akibat Perlakuan MOL Sayuran

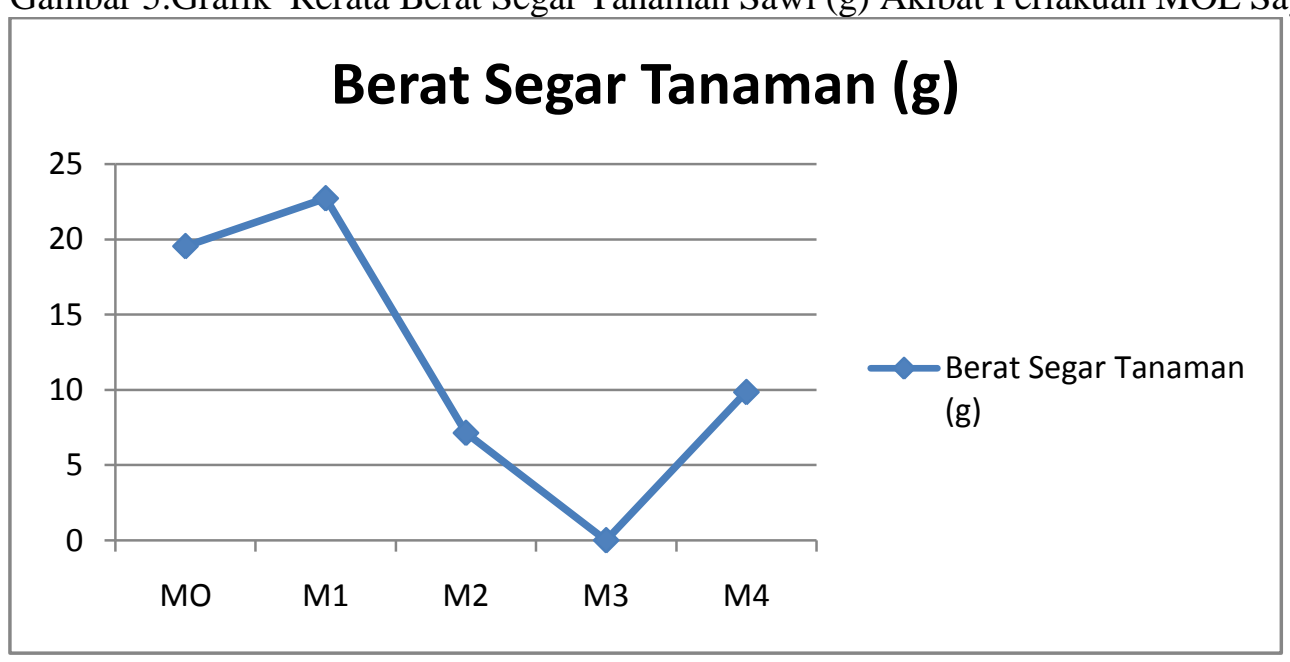


Tabel 5 dan grafik 5 diatas menunjukkan bahwa berat segar tanaman sawi setiap perlakukan mengalami fluktuasi hasil.

Perlakuan M0 secara angka menunjukkan hasil tertinggi dibandingkan perlakuan yang lain diik meskipun hasil analisa sidik ragam menunjukkan bahwa pemberian MOL sayuran berpengaruh tidak nyata terhadap berat segar tanaman sawi.

\subsubsection{Berat Konsumsi (g)}

Rerata berat tanaman yang dikonsumsi (g)akibat perlakuan MOL sayuran disajikan pada Tabel 6 .

Tabel 6. Rerata Berat Konsumsi Tanaman (g) Akibat Perlakuan MOL Sayuran

\begin{tabular}{|c|c|}
\hline Perlakuan MOL Sayuran & Rerata Berat Konsumsi (g) \\
\hline M0 $=$ Tanpa pemberian MOL & 17,76 \\
\hline M1 = Pemberian MOL75 ml/1 & 22,37 \\
\hline M2 = Pemberian MOL $150 \mathrm{ml} / 1$ & 06,41 \\
\hline M3 = Pemberian MOL $225 \mathrm{ml} / 1$ & 08,24 \\
\hline M4 = Pemberian MOL $300 \mathrm{ml} / 1$ & 08,30 \\
\hline
\end{tabular}

Tidak diuji lanjut

Gambar 6. Grafik Rerata Berat Konsumsi Tanaman (g) Akibat Perlakuan MOL Sayuran

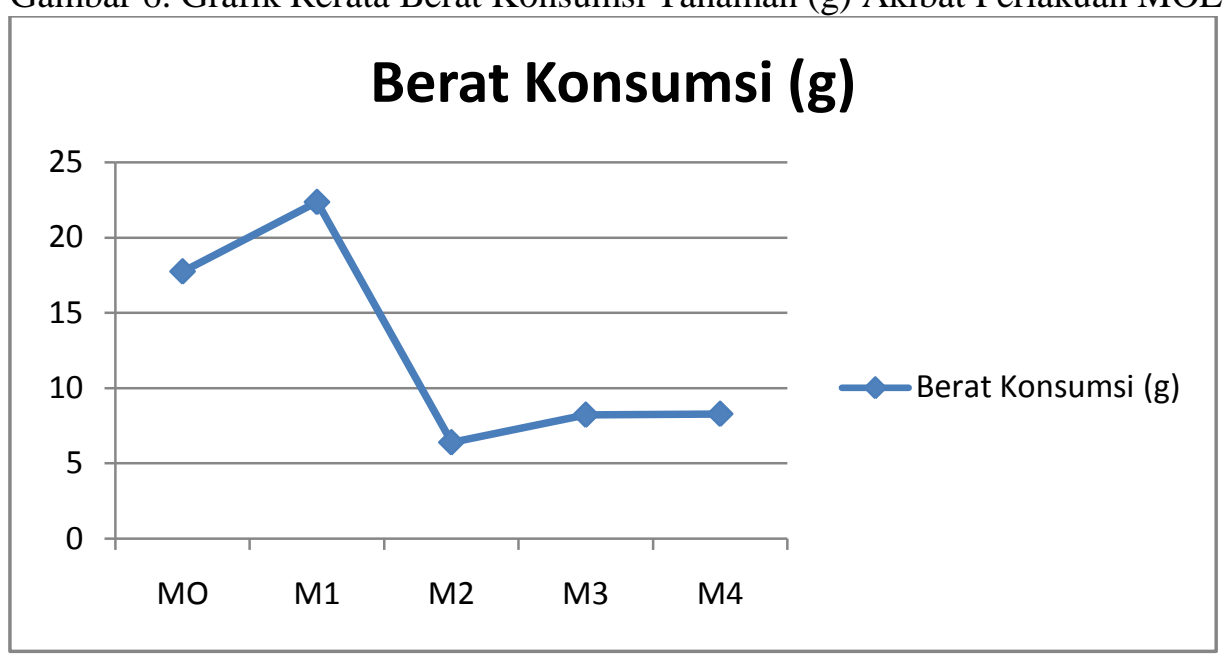

Tabel 6 dan grafik 6 diatas menunjukkan bahwa berat segar tanaman sawi setiap perlakukan mengalami fluktuasi hasil. Perlakuan M1 secara angka menunjukkan hasil tertinggi dibandingkan perlakuan yang lain meskipun hasil analisa sidik ragam menunjukkan bahwa pemberian MOL sayuran berpengaruh tidak nyata terhadap berat tanaman yang dikonsumsi.

\subsection{Pembahasan}

Berdasarkan hasil analisa sidik ragam menunjukkan bahwa pemberian MOL sayuran berpengaruh tidak nyata terhadap pertumbuhan dan produksi tanaman sawi pada semua parameter yang diamati yaitu parameter tinggi tanaman, jumlah daun pertanaman, panjang daun, lebar daun, berat segar tanaman dan berat tanaman yang dikonsumsi.

Penelitian ini dilakukan secara eksperimen dengan Rancangan Acak Lengkap non faktorial dimana semua 
kondisi lapangan kecuali perlakuan dianggap homogen, tetapi pada waktu penelitian berlangsung kondisi dilapangan pada saat musim hujan dan ternyata kondisi lokasi penelitian sebagian terendam air. Berpengaruh tidak nyatanya perlakuan diduga disebabkan pada kondisi dilapangan dimana pada perlakuan Mo (kontrol) dan M1 pada kondisi yang tidak begitu tergenang sedangkan pada perlakuan yang diberi perlakuan lain kondisi lahan pada kondisi yang tergenang. Tanah pada kondisi tergenang ruang udara dipenuhi air, mengakibatkan terjadinya perubahan karakteristik yang cepat pada tanah. Pada saat air memenuhi pori-pori tanah udara didesak keluar, difusi gas berkurang dan senyawa beracun terakumulasi akibat kondisi an aerobik. Semua perubahan ini sangat mempengaruhi kemampuan tanaman untuk bertahan hidup sebagai responnya resistensi stomata meningkat, fotosintesis dan konduktifitas hidrolik akar menurun dan translokasi fotoasimilat berkurang. Hal ini sesuai dengan pendapat Hatta (2013) yang menyatakan bahwa salah satu efek utama genangan air adalah rendahnya keberadaan $\mathrm{O}_{2}$ dibagian tanaman yang terendam karena gas $\mathrm{O}_{2}$ berdiffusi 10.000 lebih cepat di udara dibandingkan di dalam air.Kondisi tanah yang tergenang juga menyebabkan keterbatasan tanaman dalam menyerap nutrisi atau unsur hara. Penurunan energi akibat tanaman tergenang memiliki konsekuensi yang menyebabkan ketidakseimbangan dan atau kekurangan hara nutrisi (Dat et al, 2006)

Tanaman untuk tumbuh dan berkembang dipengaruhi oleh faktor genetik dan lingkungan.Secara umum dalam teknis budidaya tanaman hampir semua unsur iklim berpengaruh terhadap produksi tanaman.Namun masingmasing mempunyai pengaruh dan peran yang berbeda terhadap berbagai aspek dalam budidaya tanaman.

. Pemegang masalah utama dalam memproduksi tanaman adalah karakteristik iklim dan cuaca yang saat ini tidak beraturan dan ekstrim akibat dari pemanasan global yang terjadi. Iklim merupakan kondisi alam dalam wilayah yang luas sehingga manusia tidak dapat mengendalikan iklim dan cuaca yang terjadi.Curah hujan yang tinggi selain memiliki potensi yang menguntungkan dapat juga memberikan kerugian bagi bidang pertanian.

Secara aktual, berbagai proses fisiologi, pertumbuhan dan produksi tanaman sangat dipengaruhi oleh unsur cuaca, yaitu keadaan atmosfer dari saat ke saat selama umur tanaman, ketersediaan air (kelembaban tanah) sangat ditentukan oleh curah hujan dalam periode waktu tertentu dan disebut sebagai unsur iklim, yang pada hakikatnya adalah akumulasi dari unsur cuaca (curah hujan dari saat ke saat). Demikian juga, pertumbuhan dan produksi tanaman merupakan manivestasi akumulatif dari seluruh proses fisiologi selama fase atau periode pertumbuhan tertentu oleh sebab itu dalam pengertian yang lebih teknis dapat dinyatakan bahwa pertumbuhan dan produksi tanaman dipengaruhi oleh berbagai unsur iklim (sebagai akumulasi keadaan cuaca) selama pertumbuhan tanaman (Anonim, 2012).

BAB 5. KESIMPULAN DAN SARAN 5.1. Kesimpulan

Hasil penelitian dapat disimpulkan bahwa pemberian MOL 
sayuran berpengaruh tidak nyata terhadap semua parameter yang diamati, yaitu tinggi tanaman $(\mathrm{cm})$, jumlah daun (helai), panjang daun $(\mathrm{cm})$, lebar daun (cm), berat brangkas basah (g) dan berat konsumsi (g).

\subsection{Saran}

Disarankan untuk budidaya tanaman sawi dilakukan dalam polybag pada saat musim hujanagar mempermudah dalam pemeliharaan.
DAFTAR PUSTAKA

Anonim, 2012.Hubungan Iklim dan Pertumbuhan

Tanaman.http://mbem25.blogspot.c om/2012/05/hubungan-iklim-danpertumbuhantanaman.html.Diakses tanggal 29 Desember 2008.

Surtinah, 2008. Perancangan Percobaan Pertanian. Fakultas Pertanian. Universitas Lancang Kuning. Pekanbaru

Nazaruddin, 2003.Budidaya dan Pengaturan Panen Sayuran Dataran Rendah. Penebar Swadaya. Jakarta. 